\title{
Religion efter den sproglige vending
}

\author{
Opposition mod Lars Albinus' disputats
}

SVEND ANDERSEN

\begin{abstract}
ENGLISH ABSTRACT: The article represents my opposition against Lars Albinus' doctoral thesis on the understanding of religion under postmetaphysical conditions as outlined by Habermas and Foucault. A presentation of the main ideas in the thesis is followed by a critical discussion of Albinus' own position in philosophy of religion, primarily his understanding of religious language. The main objection is that Albinus has adopted Habermas' concept of modernity and post-metaphysics to such a degree that he accepts his implausible philosophy of language.

DANSK RESUmÉ: Artiklen repræsenterer min opposition mod Lars Albinus' doktorafhandling om forståelsen af religion på postmetafysiske betingelser som disse er angivet af Habermas og Foucault. Efter en præsentation af afhandlingens hovedtanker tages der kritisk stilling til den religionsfilosofiske position. Albinus selv forfæegter forst og fremmest hans forståelse af det religiøse sprog. Hovedindvendingen er, at Albinus føler sig så bundet til Habermas' begreb om modernitet og efter-metafysik, at han tager hans uplausible sprogfilosofi med $i$ købet.
\end{abstract}

Keywords: Religion; Modernity; Philosophy of language; Religious language

Lars Albinus' (LA) forsvar for sin doktorafhandling Religion, magt og kommunikation. Filosofiske overvejelser over religionens betydning i moderniteten, set i krydsfeltet mellem Foucault og Habermas var den sidste forsvarshandling på det daværende Teologiske Fakultet ved Aarhus Universitet. Den medvirkede dermed til at sætte punktum for en overordentlig ærværdig tradition, og man kan dårligt forestille sig en mere egnet afhandling i den rolle. Der er tale om et arbejde, som på højt niveau undersøger betingelserne for en videnskabelig beskæftigelse med religion på modernitetens vilkår - en problemstilling, der berører både religionsvidenskab og teologi. I det følgende giver 
jeg først en præsentation af afhandlingens hovedindhold, hvorefter jeg tager nogle enkelte problemstillinger op til kritisk diskussion. ${ }^{1}$

\section{De centrale tankegange}

I Indledning (s. 13-53) præsenteres anliggendet med afhandlingen som "religionens mulighed, betydning og gyldighedspotentiale i moderniteten" (Albinus 2010, 13). 'Modernitet' betyder bl.a., at fornuften er betingelse for kulturel sameksistens, hvilket dog ikke udelukker, at religion fortsat bidrager til menneskelig selvforståelse. Til temaet 'religion' hører dens forhold til både religionsvidenskab og teologi. LAs behandling af religionen sker så i lyset af forholdet mellem to fremtrædende opfattelser af moderniteten, nemlig J. Habermas' og M. Foucaults, hvis teorier karakteriseres som hhv. "magtkritisk rationalitetstænkning" og "rationaliseringskritisk magtanalytik" (s. 15). Til afhandlingens emne hører dermed også den betydning, de to har haft i nyere religionsvidenskab og teologi.

LA formulerer her en deltese for afhandlingen: Kommunikation lader sig ikke tænke i et magttomt rum - magt lader sig ikke tænke uden et mindstemål af kommunikativ indforståethed (s. 17). Med disse bestemmelser er afhandlingens titel forklaret. Afslutningsvis gives en første bestemmelse af de tre nøglebegreber kommunikation, magt og religion. Magt og kommunikation kan ikke adskilles og begge har betydning for religionen og dens politiske plads. Det antydes, at LA selv betragter religion som en ekspressiv og æstetisk størrelse.

Kapitel 2, Kommunikation (s. 55-155), behandler det første af afhandlingens tre hovedbegreber. Kapitlet gør i flere omgange rede for Habermas' teori om kommunikativ handlen, der på en gang er en sprogfilosofi (meningsteori), en handlingsteori og en teori om de vestlige samfunds rationaliseringsproces. For Habermas er et centralt socialt fænomen den på indforståethed (Einverständnis) beroende koordination af handlinger. Hans synspunkt er pragmatisk i den forstand, at 'indforståelsen' ikke bygger på en semantisk forstået udveksling af sandheder, men på ytringer, hvis prætenderede sandhed kan retfærdiggøres. Sandhed er en form for gyldighed, og Habermas tillægger den sproglige kommunikation to yderligere gyldighedsmodi, nemlig rigtighed (vedr. sociale normer) og oprigtighed/sandfærdighed (Wahrhaftigkeit). Den for de vestlige samfund karakteristiske rationalisering er præget af en differentiering af fornuften, der ifølge Habermas har sit grundlag i den sprogpragmatiske forskel mellem disse tre gyldighedsmodi.

Her indskyder LA en omtale af den tidlige Foucaults 'skepticisme', idet han sammenligner dennes vidensarkæologi med Habermas' 'efterkonstruktion' af rationalise-

1 I den indledende præsentation og i slutbemærkningen benytter jeg formuleringer, som er udarbejdet i fællesskab med de to øvrige bedømmere af afhandlingen, professor Nils Gilje, Bergen, og lektor Søren Gosvig Olesen, København. 
ringsprocessen. Foucaults epistemer har karakter af historisk apriori vidensbetingelser. Det arkæologiske projekt afløses senere af et genealogisk, hvor ekstradiskursive praksisformer inddrages. Ud fra en habermask synsvinkel fremhæver LA det rent deskriptive ved Foucaults fremgangsmåde samt hans identifikation af rationalitet med formålsrationalitet (s. 88). Foucault må betragte sin egen metode som ren og skær strategi og kan ikke etablere sammenhæng mellem beskrivelse og forklaring (s. 91). Allerede her formulerer LA en afgørende kritik af Foucault: Denne må for at gøre sit eget synspunkt forståeligt forudsætte en kommunikativ rationalitet (s. 85). Omvendt oscillerer Habermas' teori mellem "deskriptivitet og normativitet" (s. 90f.). På baggrund af denne påvisning af problemer ved begge former for "kritisk refleksion over modernitetens vilkår" formulerer LA igen det grundsynspunkt, at kommunikation indebærer en grænse, hvor vi ikke længere har noget at sige, eller hvor noget allerede er sagt os. Det er en hensigt $i$ afhandlingen at vise, at denne grænse "har med religion at gøre" (s. 92).

Habermas' kommunikationsteori er sprogfilosofisk set en 'universalpragmatik', udviklet i tilknytning til talehandlingsteorien. Dens videre sigte er spørgsmålet, hvordan en fornuftsbestemt social omgang er mulig på modernitetens betingelser. LA retter en kritik af kommunikationsteorien, der i overensstemmelse med afhandlingens anliggende vedrører påstanden om magtfrihed. Et imperativ fx 'sætter' som kommunikativ begivenhed et asymmetrisk forhold. Det fører til den mere grundlæggende kritik, at teorien om kommunikativ handlen ikke er en pragmatisk bestemmelse af de generelle forudsætninger for kommunikation, men gælder den utvungne kommunikation mellem ligeværdige parter som grundlag for gensidigt forpligtende handlen (s. 141f.). Eller, spørgende formuleret: "Er reglen om normativ indforståelse en for al sprogbrug nødvendig, eller blot ønskværdig, regel?" (s. 144).

Kapitel 3 handler om det andet af afhandlingens tre hovedbegreber: Magt (s. 157259). Fra en minimal bestemmelse af magt som mulig tvang når LA videre gennem diverse magtbegreber tilbage til deres filosofihistoriske udspring hos bl.a. Hobbes og Hume. I det perspektiv behandles så både Foucaults og Frankfurterskolens magtbegreb.

Foucaults magtbegreb placeres i en historisk kontekst (s. 176f.), og LA undersøger, om der ikke ligger en magtteori under, hvad Foucault kun vil kalde magtanalytik (s. 178). LA forsvarer i denne forbindelse Foucault over for anklagen om, at hans kritik er ugyldig grundet mangel på alternativ. LA finder nu et fodfæste i sit komparative arbejde og siger, at

Foucault har bedre [end Habermas] blik for sammenhænge, som går på tværs af fornuftsargumenters interne domæne i den forstand, at en menneskelig praksis involveres i magtrelationer, der til forveksling kan ligne rationelt etableret konsensus (s. 234).

Herefter argumenterer LA for religionens emne og kalder det måske lidt postulerende "overordentligt centralt" for "diskussionsfeltet mellem Foucault og Habermas" (s. 257). Men kapitlet rummer også formuleringer, der viser, at LA er opmærksom på faren for, at religionens "kontekstualisering" kan komme til at skygge for religionens sag. LAs 
pointe er her, "at man under ingen omstændigheder har afskaffet problemet ved at afskaffe religionsbegrebet" (s. 231).

$$
\text { Religion og religionsvidenskab }
$$

Kapitel 4, Religion (s. 261-641), behandler afhandlingens tredje hovedbegreb. LA åbner med at påpege at religionsbegrebet på mange måder er essentielt omstridt. De forskellige forsøg på at definere 'religion' kan forstås som begrebspolitik, og netop den akademiske strid om definitionen viser ifølge LA, at allerede på dette præliminære niveau er magt og rationalitet uløseligt sammenvævet.

I forholdet mellem nominalistiske og realistiske definitioner af religion indtager LA tilsyneladende en formidlerposition. Han er i udgangspunktet kritisk over for den traditionelle religionsfænomenologis essentialistiske forståelse af religion som 'egenrealitet', 'erfaring', 'virkelighed sui generis' etc. Ifølge LA må al såkaldt religiøs 'erfaring' sprogliggøres, så hvis religionsfænomenologien gennemfører en 'sproglig vending', vil nogle af de sædvanlige indvendinger mod denne fagtradition falde bort. På den anden side er heller ikke nominalistiske bestemmelser af religion uproblematiske måske primært fordi de tenderer mod at eliminere aktørernes selvforståelse. LA går mere i dybden i forhold til denne diskussion i sin gennemgang af striden mellem Comparative Studies of Religion (CSR) og Religious Studies (RS). Igen forsøger LA at formidle mellem to tilsyneladende uforenelige positioner, der beskylder hinanden for hhv. teologisk orienteret 'kognitiv imperialisme' og forsøg på at eliminere religionsbegrebet.

LA behandler etnocentrismeproblemet og knytter til ved Gadamer og Taylor. I tråd med sidstnævnte understreger LA, at mennesket er et selvfortolkende dyr - og at dets selvfortolkninger er en del af den sociale realitet, som forskeren studerer. Derfor er det problematisk at give beskrivelser eller forklaringer på adfærd, som aktørerne umuligt kan acceptere som rimelige beskrivelser eller forklaringer af deres handlinger. LA påpeger at der kun findes en vej ud af etnocentrismeproblemet: "at tage de 'andre' alvorligt som handlende individer" (s. 282). Ved den afsluttende præsentation af Habermas' syn på det mytiske verdensbillede synes LA at have problemer med denne del af teorien om kommunikativ handling. Han påpeger, at man naturligvis kan "stille spørgsmålstegn ved, om forståelsen af myte-begrebet som et billede af verden, der lukker sig om sig selv, ikke er for snævert" (s. 289). LA påpeger også, at Habermas' mytebegreb måske "netop gør vold på princippet om at fastholde et deltagerperspektiv" (s. 289). Dermed er vejen banet til en behandling af religionsbegrebet "i Habermas' og Foucaults optik". Fælles for de to er, at forholdet til religion er bestemt af en post- og antimetafysisk tænkning. Habermas' syn på religion fremstilles under tre overskrifter: det mytiske verdensbillede, sekulariseringens udviklingslogik og bestemmelsen af transcendens på eftermetafysiske betingelser. Hvad angår Habermas' opfattelse af myten, fremhæves hans påstand om manglende skelnen mellem sprog og verden og 
fravær af differentiering af gyldighedsmodi. Dermed er myten immun over for kritik og læreprocesser.

I behandlingen af sekulariseringsprocessen fremhæver LA Habermas' hævdelse af en sammenhæng mellem fremkomsten af dels den kommunikative handlen og rationalitet, dels sprogliggørelsen af det sakrale. LA omtaler den indvending, at Habermas forudsætter et reduktionistisk religionsbegreb ved at se bort fra religiøs erfaring. Problemet med sidstnævnte er dog for LA, at det peger i retning af 'bevidsthedsfilosofi', men han antyder at det kan opfattes som hørende til en intersubjektiv erfaringsdimension. Religion vedrører noget allerede sagt og gjort, en magt, som tænkes bort i den kommunikative model (s. 320). Som afslutning på fremstillingen af Habermas' religionsopfattelse går LA ganske udførligt ind på hans stillingtagen til studenteroprøret i 1968 og dets følger.

I det efterfølgende afsnit om religionens tema hos Foucault behandles de artikler, Foucault skrev til Corriere della sera i forbindelse med den iranske revolution. De skal, som LA fremhæver, anvendes med forsigtighed, og det lykkes LA ganske præcist at placere Foucault og hans epokes intellektuelle og derudfra bestemme, hvilken rolle religionen kan spille for en sådan intellektuel (s. 438f. 444f.). I forhold til marxismens ord om religionen som folkets opium nuancerer LA billedet ved med Foucault at minde om, at religionen ifølge Marx også er ånden i en verden uden ånd (s. 439). I sin gennemgang af Foucaults Iran-artikler paralleliserer LA (s. 442. 444) med Heideggers politiske naivitet, og han gør opmærksom på, hvordan Foucault i modsætning til Heidegger gentagne gang er vendt tilbage med kommentarer til eftervirkningerne af de politiske begivenheder, han i det mindste i medierne involverede sig i. LA mener, at det, Foucault så i opgøret i Iran, primært var et opgør med en lineær progression (s. 444).

LA vender tilbage til religionsvidenskaben og diskuterer to grundparadigmer, et naturalistisk og et ikke-naturalistisk. Det naturalistiske er ifølge LA funderet i en grundlæggende reduktionistisk antagelse: Religion skal forklares ud fra noget andet end religionen selv. Derimod betragtes i det ikke-reduktionistiske paradigme religion som en kategori sui generis. LA placerer sig i hovedsagen inden for det ikke-naturalistiske paradigme. De mest centrale retninger inden for det naturalistiske paradigme tilhører ifølge LA den religionssociologiske og antropologiske tradition fra Durkheim, Malinowski o.a. Her reduceres religion til social funktion. Nyere kognitionspsykologisk teori søger derimod at forklare adfærdsformer og trosforestillinger ud fra universelle dispositioner (schemata eller templates). En tredje retning baserer sig på en socialkonstruktivistisk og nominalistisk forståelse af religion: inspireret af Foucault betragtes religion som en "strategisk diskursformation", som udelukkende tjener sociale og politiske formål. Religion reduceres tendentielt til politik eller forklares som politisk strategi (s. 452). LA fremsætter en kritik af hovedtendensen inden for det naturalistiske paradigme: For alle traditionerne gælder, at de på forskellig måde møder et selvreferenceproblem, fx er den religionsvidenskabelige kognitionsforskning "i grundlæggende forstand performativt selvmodsigende" (s. 454). Disse traditioner kan siges at afvise, 
hvad personer hævder om sig selv, så deres religiøse selvforståelse bliver irrelevant, hvorved der blokeres for dialog (jf. s. 462). Som kontrast får vi en bred oversigt over kritisk hermeneutik som tilgangsmåde inden for en ikke-naturalistisk religionsforskning. Der er tale om en position, som LA tilslutter sig.

$$
\text { Religion og æstetik }
$$

Diskussionen af Habermas' opfattelse af religionen peger på den opgave at bringe det erfaringskompleks "i spil", der er knyttet til et æstetisk og religiøst betydningspotentiale uafhængigt af de abstrakte formale gyldighedskrav (s. 529). LA går i lag med opgaven i afsnittet "Religion som æstetisk erfaring", der må opfattes som afhandlingens konstruktive centrum. Opgaven er filosofisk at bestemme muligheden for at tænke religion og æstetik på modernitetens betingelser uden at være dikteret af kravene til fornuftens offentlige brug, men dog ud fra en 'uigendrivelig' modernitetserfaring, der indbefatter eftermetafysisk tænkning. Det religionsfilosofiske projekt er formuleret på habermaske betingelser, for så vidt som religion er opfattet som "genstandsfelt for ekspressive udsagnsbetingelser" (s. 530). Det stilles i udsigt, at religionen vil vise sig at indebære en modifikation af både Habermas' kommunikationsteori og Foucaults magtanalytik.

I et afsnit om kunst og religion påpeger LA, at kunst i et habermask perspektiv ikke fremstiller en objektiv realitet på samme måde som konstative talehandlinger. Følgelig har Habermas vanskeligt ved at forholde sig til Adornos begreb om "æstetisk sandhed". Da de differentierede gyldighedskrav er principielt uafhængige, har kunsten ingen sandhedsværdi på linje med konstative ytringer. I tråd med A. Wellmer åbner LA imidlertid for en 'opblødning' af Habermas' begrebsmæssige arkitektur ved at henvise til "den gensidigt involverede sammenhæn mellem forskellige gyldighedsafgørelser" og "glidende overgange mellem forskellige 'sandhedsbegreber"” (s. 544).

Afsnittet om "Foucaults æstetiske spiritualitet" bringer den franske strukturalisme i erindring og diskuterer forbindelsen til Heidegger. LA resumerer Foucaults tale om at "forme sit eget liv som et kunstværk" (fx s. 591). Hvis der findes en foucaultsk etik, findes den "ganske vist kun indirekte, nemlig i historisk klædedragt" (s. 605). Foucault tages til indtægt for, hvad der kaldes "den situationistiske etik", som placerer "refleksionens objektive, intersubjektive og subjektive karakter" i "en æstetisk horisont."

Sammenstillingen af afhandlingens to hovedpersoner bringes til afslutning i afsnittet "Det æstetiske omdrejningspunkt: Habermas og Foucault mødes og skilles igen." LA minder om, at Habermas ikke deler Benjamins og Adornos opfattelse af det æstetiske. Og hvad Foucault angår, kategoriserer han dennes æstetik som 'ungkonservativ', hvilket dog for LA er "for hurtigt" (s. 621). Efter en ekskurs om æstetik som aktionisme under studenteroprøret diskuterer LA sensibilitetens plads hos hans to 'dialogpartnere'. Hos Foucault er der tale om en 'hypersensitivitet', der er så personlig, at den ikke kan gentages. Hos Habermas 'snøres' sensibiliteten sammen i "en sæk af subjektive præferencer" (s. 635). Med betoningen af den herredømmefri dialog underkendes mag- 
terelationerne og den eksistentielle motivationskraft. Habermas brænder for fornuften, "hvilket ubetinget har min største respekt." Men: “Æstetisk betragtet er TKH et hus uden beboere af kød og blod" (s. 637). Kun en æstetisk grunderfaring, der giver afkald på volden, kan gå hånd i hånd med fornuftsgevinsten (s. 643).

Konklusion (s. 644-654) afrunder afhandlingen. LA gentager sin opfattelse af, at Habermas og Foucault modificerer hinanden: Ved den rationelle kommunikation sniger magten sig ind på overgangen til praksis - og en kritik af magt må altid forudsætte en form for fornuft (s. 645f.). De religiøse affiniteter ligger dels i, at Habermas' kommunikationsteori ikke er uforenelig med den kristne forestilling om en Gud, der i kærlighed giver sin magt fra sig til ansvarlige mennesker, dels i Foucaults påpegning af en åbenhed for den menneskelige værens uafgjorte og formbare karakter og dens forhold til en 'uransagelig' magt.

\section{Kritik af Albinus' religionsfilosofi}

Efter denne oversigt over væsentlige dele af afhandlingens indhold - set med bedømmelsesudvalgets øjne - vil jeg nu for egen regning tage nogle enkelte problemstillinger op til kritisk diskussion. ${ }^{2}$ Hvad der i den henseende forekommer mig mest interessant, er den religionsfilosofiske position, LA forfægter i sin afhandling. Skønt han forsøger at dele sol og vind lige mellem Habermas og Foucault, fremstår positionen klarest ud fra den måde, han udvikler den i kritisk diskussion med Habermas. For mig at se er kernen i sagen forholdet mellem religion og sprog. En af de ting, LA forudsætter næsten som et aksiom, er nemlig den såkaldte sproglige vending, og det må jo betyde, at det religionsfilosofiske hovedproblem er, hvordan vi skal forstå det religiøse sprog. Derfor skal vi også diskutere Habermas' sprogfilosofi, idet det som nævnt er ud fra denne, LA formulerer sin egen opfattelse. Min påstand er, at LA alt for ukritisk godtager Habermas' sprogfilosofi, og at det resulterer i en højst diskutabel opfattelse af det religiøse sprog. Men lad os begynde med selve den sproglige vending. LA definerer eller beskriver den på følgende måde:

[E]nhver reference til noget før- eller ekstrasprogligt [er] allerede (...) så indfældet $\mathrm{i}$ sprogligheden, at vi under alle omstændigheder må medtænke måden, hvorpå vi fremsætter ytringer om en given realitet. (s. 56).

Det forekommer mig at være en noget vag formulering, der ikke lader pointen ved den påståede sproglige vending fremtræde særlig klart. Man plejer at betragte den afdøde amerikanske filosof Richard Rorty som en af ophavsmændene til betegnelsen, ${ }^{3}$ og hans formulering af den lyder:

2 Det følgende er en bearbejdet version af min mundtlige opposition.

3 Ifølge Rorty selv er det nok mere nøjagtigt at tilskrive udtrykket den østrig-tyske filosof Gustav Bergmann, 
[T] he view that philosophical problems are problems which may be solved (or dissolved) either by reforming language, or by understanding more about the language we presently use (Rorty 1992, 3).

Her drejer det sig altså ikke blot om det begrænsede fænomen at referere til noget uden for sproget, men meget mere grundlæggende om betingelserne for at løse filosofiske problemer. Den prægnante betydning af talen om en sproglig vending ligger da også i, at sproganalysen har status af filosofisk grunddisciplin. Det er opfattelsen hos den tyske filosof Ernst Tugendhat, for hvem filosofi ikke er en empirisk videnskab, men en eksplikation af en forståelse, som ligger implicit i empirisk viden. Og denne eksplikation kan kun opnås gennem filosofisk sproganalyse. Vendingen til sproget er for Tugendhat en vending bort fra antikkens naive ontologi og den nyere tids lidt mindre naive bevidsthedsfilosofi (Tugendhat 1976, 19ff.). En tilsvarende opfattelse finder vi hos den engelske filosof Michael Dummett. Efter en præsentation af de vigtigste former for angelsaksisk analytisk filosofi og en påpegning af den store forskel mellem fx den mere logisk orienterede og den såkaldte dagligsprogsfilosofi bemærker han, at alle former var bestemt af "the linguistic turn": "The study of language, whether systematic or piecemeal, was substituted for the study of thought" (Dummett 2010, 88). Jeg er tilbøjelig til at sætte lighedstegn mellem Tugendhats 'Verstehen' og Dummetts 'thought' og gengive deres opfattelse af den sproglige vending på følgende måde: Filosofiens opgave er at komme til klarhed over de grundlæggende måder, vi forholder os til virkeligheden på. Og den opgave kan kun løses gennem en analyse af sprogets funktion, eller med Dummetts formulering: af, hvad det vil sige at forstå sproglige udtryk.

Ifølge både Tugendhat og Dummett er den sproglige vending kendetegnende for analytisk filosofi. LA mener derimod, at den også er gennemført i fransk filosofi - hvilket vel også er en vigtig forudsætning for, at det giver mening at sammenligne Habermas og Foucault. Men 'sproglig vending' betyder så igen noget temmelig vagt, nemlig den påstand, at det at have et begreb er ensbetydende med at kunne anvende tegn (Albinus 2010, 60). LAs sprogfilosofiske udgangspunkt bliver ikke mere klart af, at han foruden den sproglige også antager en pragmatisk vending (s. 57). Denne står ifølge LA i modsætning til den semantiske teori, vi finder hos den analytiske filosofis ophavsmand Gottlob Frege (s. 110). Hvis man ved pragmatisk forstår sprogets brugsaspekt, er det imidlertid misvisende at stille denne 'vending' i modsætning til Frege, idet denne netop ved siden af 'Sinn' (mening) og 'Bedeutung' (reference) opererer med ytringers 'behauptende Kraft'.

Min første indvending mod LAs religionsfilosofiske position er således, at det begreb om sproglig vending, som er en afgørende forudsætning for positionen, er alt for vagt formuleret. Jeg ville selv formulere den sproglige vending i en religionsfilosofisk sammenhæng nogenlunde sådan: En filosofisk forståelse af og kritisk vurdering af en religiøs virkelighedsforståelse må have karakter af en analyse af det sprog, denne

jf. Rorty 1992, 9. 
forståelse kommer til udtryk i. En sådan analyse forudsætter en bestemt filosofisk teori om sproget. Det gælder også Habermas, og derfor må vi nu se lidt nærmere på hans sprogfilosofi.

$$
\text { Habermas' sprogfilosofi }
$$

I hvilken forstand er der hos Habermas tale om en sprogfilosofi, og hvilken karakter har denne? Habermas selv bruger - begyndende så tidligt som i 1970'erne - betegnelser som 'formalpragmatik' og 'universalpragmatik', men også 'teori om kommunikativ kompetence'. 'Pragmatik' indikerer, at det, som interesserer Habermas, er sproget som praksis, handling, hvorfor han knytter til ved den sene Wittgenstein og ikke mindst speech act-teorien hos Austin og Searle. Men hvad er en pragmatisk sprogfilosofi? De udtalelser af Rorty og Dummett, jeg citerede ovenfor, viser begge, at analytisk sprogfilosofi kan betyde to forskellige ting: (1) en undersøgelse af udvalgte sproglige vendinger, med det formål at kaste lys over bestemte filosofiske problemstillinger; (2) et forsøg på at formulere en omfattende og sammenhængende teori om, hvordan sprog i det hele taget fungerer, med det formål at indkredse grundtræk ved menneskers relation til virkeligheden. Det sidste projekt kalder Dummett 'theory of meaning' og Tugendhat er en af dem, der har grebet projektet mest systematisk an. Problemet med sprogfilosofien som meningsteori er, at den indtil videre kun har haft begrænset succes. Enten gælder teorien kun formaliserede sprog, eller den gælder en meget begrænset del af naturligt sprog.

Det problem synes også at rejse sig for Habermas' sprogteori. Her finder vi forskellen mellem formalsprog og naturligt sprog (dagligsprog) i form af distinktionen mellem diskurs og livsverden-sprog. I livsverdenen forudsætter vi mere eller mindre naivt, at de gyldighedskrav, vi forbinder med sproglige ytringer - Habermas fremhæver som nævnt sandhed, rigtighed og sandfærdighed - er opfyldt. Diskursen er derimod den særlige sprogpraksis, hvor vi tematiserer problematiserede gyldighedskrav og gennem argumentation forsøger at overbevise hinanden om, at de er enten opfyldt eller ikke opfyldt. Det ideelle mål med diskursen er konsensus, hvilket svarer til, at sproget som iboende telos har 'Verständigung'. Dette centrale udtryk betyder hos Habermas ikke kun forståelse (Verstehen), men at komme til forståelse med hinanden. Man kan i høj grad stille spørgsmålstegn ved, om den intention at opnå 'Verständigung' er en nødvendig betingelse for, at sprog fungerer. Når Habermas lægger vægt på dette begreb, kan det tages som indicium for, at han ikke ønsker at formulere en teori om al slags sprog, men primært om diskursen. ${ }^{4}$

Det pragmatiske aspekt ved sproget - dets handlingskarakter - består for Habermas i, at vi, i og med at vi fremsætter ytringer over for en kommunikationspartner, knytter gyldighedskrav til ytringerne og dermed udfordrer partneren til at tage stilling til og

4 Til den sprogfilosofiske forskel mellem livsverden og diskurs se fx Habermas 1973, 217f.; 1974, $114 \mathrm{ff}$. 
anerkende deres gyldighed. Habermas anfører et sted det meget enkle eksempel ‘Peter ryger pibe' (Habermas 1976, 224). En konkret ytring kunne være ‘Du må ikke ryge pibe, Peter'. Ifølge speech act-teorien skal ytringen opdeles i to elementer: det såkaldte propositionale indhold 'at Peter ryger pibe' og den illokutionære markør, der angiver, hvilken talehandling det drejer sig om, i dette tilfælde 'du må ikke', der angiver et forbud, hvilket forudsætter, at en bestemt social norm er gyldig (rigtighed). Det er i kraft af den illokutionære markør, ytringen indgår i social handlen, for med denne markør udfordrer eller indbyder taleren sin partner til at tage stilling til ytringens gyldighedskrav.

Spørgsmålet er nu, hvor meget en pragmatisk teori yder sprogfilosofisk. Kan man klare sig uden semantik? Forenklet sagt ligger semantikken i det propositionale indhold, der i sin mest enkle udgave består i at der om en enkeltperson eller ting (Peter) anvendes et prædikat (ryger pibe). En semantisk analyse handler om, hvordan vi med singulære udtryk refererer til enkeltfænomener, hvordan vi anvender prædikater - og hvordan singulære udtryk og prædikater hver især bidrager til et helt udsagns betydning og gyldighed. Tilsyneladende godtager Habermas, at en semantisk analyse skal forløbe ad de baner, men han forklarer, så vidt jeg kan se, ikke, hvordan semantik og pragmatik kan virke sammen i en sprogfilosofi eller meningsteori. Dog kan man finde antydende formuleringer af en pragmatisk 'revideret' sandhedssemantik som denne:

At forstå en påstand vil sige at vide, hvornår en taler har gode grunde til at påtage sig garantien for, at betingelser for det hævdede udsagns sandhed er opfyldt (Habermas 1981, 426; min oversættelse).

Det må dog snarere forstås som en programerklæring end som fremlæggelsen af en meningsteori. Noget tyder på, at Habermas i løbet af udviklingen af sin sprogteori nedtoner det semantiske. I de tidlige arbejder opererer han med en fjerde gyldighedsform, nemlig 'Verständlichkeit', der netop indebærer, at også meningen med ytringers propositionale indhold skal være forståeligt. En talers bidrag til at gøre sin ytring forståelig kalder han for øvrigt tydning (jf. Habermas 1973, 220). I et relativt sent værk antyder Habermas selv, at semantikken hører til de 'forsømte' dele af hans filosofi (Habermas 2004, 7). I den samme bog findes udtalelser, der tyder på teorien om den kommunikative handling først skal udbygges til en meningsteori (fx s. 95ff.).

LA taler flere steder om Habermas' meningsteori (fx s. 529. 554. 648). Men han fremhæver andre steder "den omstændighed ved sproget, at det åbner verden og åbenbarer menneskets inderste væsen" (s. 153). Det sker i tilknytning til Gadamer og Benjamin. LA diskuterer i det følgende, om dette aspekt ved sproget kan finde plads i Habermas' meningsteori. Det er dog svært at se, hvilken konklusion han når frem til. Og efter min mening er det vanskeligt at forestille sig, hvordan en analytisk meningsteori kan forenes med Gadamers hermeneutiske sprogopfattelse. Sådan ser det i hvert fald ud fra Dummets analytiske synsvinkel: 
The contrast between Frege's and Gadamer's approaches to language is stark. From Frege we get sharp, detailed, innovative analysis; from Gad[a]mer, ruminations at a high level of generality. Which approach is found more illuminating is a matter of temperament (Dummett 2010, 97).

Min foreløbige konklusion er, at Habermas ikke lader karakteren af sin sprogteori fremtræde klart. Jeg synes heller ikke, det lykkes LA at bidrage til større klarhed. Det må naturligvis have konsekvenser for analysen af det religiøse sprog.

$$
\text { Det religiøse sprog }
$$

Hvis man i forståelsen af det religiøse sprog orienterer sig ud fra Habermas' sprogopfattelse, må et grundspørgsmål blive, hvordan religiøst sprog skal placeres i forhold til de tre gyldighedsmodi. Et første vigtigt spørgsmål er da, om det giver mening at operere med religiøse udsagn, konstativer, der hævdes at være sande. Det gør det tilsyneladende ikke ifølge Habermas. Men om han har ret, afhænger jo af, hvad vi skal forstå ved konstativer og sandhedens gyldighedsmodus.

Habermas taler mange steder om, at de tre gyldighedsmodi svarer til tre former for verdensrelation: Sandhed svarer til en objektiv verden af genstande; rigtighed svarer til en social normreguleret verden og sandfærdighed svarer til en subjektiv verden eller en indre natur (se fx Habermas 1981, 414). I afhandlingen omtales denne tredeling (Albinus 2010, 116f.); men er det rigtigt, at konstativer altid forholder sig til en objektiv verden af genstande? Svaret er ikke helt klart hos Habermas. I "Wahrheitstheorien" siger han, at konstativer kan være beskrivelser og fortællinger. Men kan fortællinger ikke handle om den intersubjektive sociale verden og kan de i så fald ikke være sande? Og er beskrivelser af verden altid 'objektive'? Har Habermas ikke et for snævert begreb om, hvad konstativer forholder sig til? LA anfører faktisk et udmærket eksempel, der peger i den retning: 'Bussen skulle komme om fem minutter' (s. 541). Der er uden tvivl tale om en ytring med deskriptiv karakter. Men er det dækkende at sige, at den, der ytrer den, gør krav på, at den er sand og udfordrer tilhøreren til at godtage eller afvise sandhedskravet? Deskriptive eller konstative sætninger har åbenbart en langt mere mangfoldig betydning, end Habermas tillægger dem. Hans teori om konstativer tillader derfor ikke den konklusion, at deskriptive religiøse udsagn ikke giver mening eller kan være sande.

LA følger imidlertid Habermas og mener, at religion snarere skal forstås ud fra de to andre gyldighedsmodi rigtighed og, ikke mindst, sandfærdighed. I forbindelse med rigtighed foretager Habermas i øvrigt en vigtig skelnen mellem moralske normer og etiske værdier. Dermed bliver det sprog, som styres af rigtighedens gyldighedsmodus meget forskelligartet og komplekst. Under alle omstændigheder skal religiøse udsagn forstås som en form for værdiudsagn. Det ser jeg imidlertid bort fra. Det er nemlig 
mere vigtigt, hvad LA har at sige om religionens forbindelse til sandfxrdighed, altså den tredje af Habermas' gyldighedsmodi.

Hvad gemmer der sig i det hele taget bag denne gyldighedsmodus: 'Wahrhaftigkeit'? LA giver som eksempel udsagnet "Jeg har ondt i maven" (s. 117). Men det forekommer mig at være meget uheldigt. Habermas definerer sandfærdighed som det at mene intentioner, som de er ytret (Habermas 1973, 236). En intention er noget andet end en smerte! Et bedre eksempel kunne være 'Jeg ønsker dig en glædelig jul': sandfærdighed betyder, at den talendes subjektive indstilling svarer til den velvilje mod den tiltalte, sætningen udtrykker. Derfor giver det mening, at Habermas som modsætning til sandfærdighed fremhæver forstillelse og selvbedrag. Det er også forståeligt, at han taler om repræsentative talehandlinger som at tilsløre, fordunkle, hemmeligholde osv. (s. 228). Men det forekommer mig, at Habermas udvider omfanget af, hvad sandfærdighed dækker. Han taler nemlig også om "expressive Selbstdarstellung" og om det, at "subjektive oplevelser kommer til syne" (Habermas 1981, 35; min oversættelse). Her opererer han ligefrem med ekspressiver som en særlig klasse af talehandlinger (ikke kun en særlig gyldighedsdimension ved alle talehandlinger) (s. 436). Alvoren af en ytret intention og en ekspressiv selvfremstilling er imidlertid to for forskellige sproglige fænomener til, at det er berettiget at henføre dem til samme gyldighedsmodus. Hvad der nu imidlertid er særlig vigtigt - også for LAs religionsfilosofiske position - er, at Habermas også forstår kunsten inden for sandfærdighedens gyldighedsdimension. Habermas omtaler gerne kunst som 'efter-auratisk' ud fra Walter Benjamins berømte tese om auraens forsvinden med kunstværkets tekniske reproducerbarhed. I parentes bemærket mener jeg ikke, at Benjamin frakender al moderne kunst aura i betydningen “einmalige Erscheinung einer Ferne, so nah sie sein mag." Men for Habermas er moderne kunst jegets omgang med sig selv (Habermas 1982, 139). Æstetisk kritik vedrører efter hans opfattelse krav om autenticitet og er i øvrigt den form for argumentation, der støtter værdier (Habermas 1981, 41).

\section{Lars Albinus' religionsfilosofi}

Efter i tilknytning til LAs afhandling at have fremhævet nogle problematiske punkter i Habermas' sprogfilosofi vil jeg nu til slut kommentere LAs egne religionsfilosofiske overvejelser. LA beskæftiger sig først med religiøse talehandlinger. Og det er velgørende, at han ikke taler generelt og abstrakt, men ud fra konkrete forekomster af religiøst sprog. Hans eksempel er velsignelse. Om den siger han, at talehandlingen har en perlokutionær effekt, og at ytringen effektuerer udsigelsens reference i kraft af sig selv. Intentionen er udsagnets eget. Nu diskuterer LA velsignelsen i formen "Jeg velsigner dig". Her kunne jeg have ønsket mig en endnu højere konkretionsgrad, for i den kristne gudstjeneste hedder det som bekendt "Herren velsigne dig," så talehandlingen er nok mere kompleks end som så. LAs hovedpointe er imidlertid, at den religiøse talehandling ikke kan indpasses i et habermask gyldighedsskema. Man kan ved velsignelsen 
hverken tale om etisk-eksistentiel eller æstetisk-subjektiv gyldighed. Gyldigheden af velsignelsen forudsætter henvisning til en magt eller taledimension uden for fællesskabet af diskursdeltagere. Religionens magt eller den religiøse diskurs' illokutionære kraft består i "henvisningen til en transcendent diskursdeltager" (Albinus 2010, 535f.). Hvad det vil sige, at velsignelsen forudsætter en henvisning til en transcendent magt, vender vi tilbage til. I første omgang er det vigtigt at konstatere, at den religiøse talehandling ifølge LA ikke kan forstås adækvat ud fra Habermas' tredeling af gyldighedsmodi.

Mit næste spørgsmål vedrører det sproglige slægtskab mellem religion og kunst. LA gør rede for den kritik, der er blevet rettet mod indordningen af kunsten under ekspressive talehandlinger, hhv. sandfærdighedens gyldighedsmodus. Kunstværket kan ikke siges at fremsætte en talehandling og kan alene af den grund ikke "rubriceres under ekspressive talehandlinger". Derimod kan det "i recipientens fortolkningsbidrag udløse tilfredsstillelsen af et sandhedspotentiale" (s. 549). Dette sandhedspotentiale har åbenbart noget at gøre med den verdensåbning, sproget yder, for LA taler om den æstetiske erfarings verdensåbning (s. 554). LA synes ikke at godtage Habermas' forsøg på at placere kunsten under sandfærdighed, eller hans tale om, at kunsten udtrykker jegets omgang med sig selv. Også i forhold til denne problemstilling kunne jeg dog have ønsket mig en inddragelse af konkrete eksempler. I diskussionen om, hvad et kunstværk er, har digterne vel også ret til at blande sig. Jeg vil give ordet til Søren Ulrik Thomsen, der i sin anden poetik En dans på gloser - eftertanker om den kunstneriske skabelsesproces siger:

... i poesien er jeg kun et eksempel og mister netop sin værdi som sådant, hvis det styres af digterens individuelle psyke, om end denne, ydmygt underordnet det eksistentielle, naturligvis funger som brændstof og tilskyndelse og derfor også signerer teksten med slagger fra ophavets personlige liv, hvis betydning for teksten jeg ikke underkender (Thomsen 1986, 42).

Det afgørende ved digtet er, at det personlige stof transformeres til form. Kunsten bliver dermed altid et mellemværende med tilværelsen (s. 28). Og videre:

Det vellykkede digt huser en blind vinkel, hvorfra ny betydning til stadighed emanerer, og kan derfor ikke endegyldigt beskrives af analysen, eller sagt på en anden måde: nye analyser vil blot få denne vinkel til kontinuerligt at forskyde sig, idet enhver analyses mål er at udsige alt det den ved om digtet, hvorved den samtidig analyserer sig frem til det, netop denne analyse ikke ved (91).

Thomsen taler om digtets hemmelighed. Kunne man ikke også kalde det aura? - Hvis Søren Ulrik Thomsens beskrivelse af den digteriske proces står til troende - og hvorfor skulle man betvivle det? - er det digtets prætention at udsige noget sandt om virkeligheden uden at underkaste sig en objektiverende gyldighed. LA er tilsyneladende 
ikke uenig i denne kritik af Habermas' kunstforståelse, for han fælder (som tidligere nævnt) en ganske drastisk dom om Theorie des kommunikativen Handelns: “Æstetisk betragtet er TKH et hus uden beboere af kød og blod." (Albinus 2010, 637). Det spørgsmål, man som læser af hans afhandling så blot må stille, er: Hvorfor da vælge netop Habermas som forståelsesbaggrund for det æstetiske og religiøse sprog?

Svaret er formentlig, at det er mere vigtigt for LA at bevæge sig på sikker moderne og postmetafysisk grund end at have en overbevisende sprogfilosofi til rådighed. I hvert fald finder LA, at der "gemmer sig en komprimeret religionsfilosofi" i Habermas' postmetafysiske standpunkt (s. 646). Denne religionsfilosofi indebærer, at den kristne tradition fortolkes ud fra grundforestillingen om en Gud, der i kærlighed til sin skabning har givet magten fra sig og tildelt mennesker det afgørende ansvar for sig selv (ibid.). I tilknytning til Foucault må LA imidlertid fastholde, at magten ikke kan elimineres af religionen. Her forholder mennesket sig tværtimod til en magt, som overskrider dets egen formåen (s. 650). Den kan ikke placeres hos nogen, men er indskrevet i sproget selv, bl.a. i den religiøse overlevering. Magten som udtryk for kontingensens betingelser, i den historiske overlevering som postulat om magten hos den elskende, retfærdige og dømmende Gud (652).

Her vil jeg vende tilbage til spørgsmålet om den transcendente diskursdeltager, der forudsættes i den kristne velsignelse. Hvad bliver der af denne reference til Gud i LAs religionsfilosofi? Foretager han en bevægelse fra afmagt over for kontingensen til en ikke-menneskelig form for magt? I traditionen er dette udtrykt i tanken om én magt, nemlig Gud. Skal LAs afsluttende formuleringer forstås sådan, at det religiøse sprogs reference til Gud ikke giver mening på eftermetafysiske og den sproglige vendings betingelser? Hvad der før kaldtes Gud, findes nu som en magt i traditionen. Hvis det er konklusionen, har LA vist det eftermetafysiske for stor respekt - og den sproglige vending for lille.

\section{Slutbemærkning}

Efter bedømmelsesudvalgets mening har Lars Albinus fremlagt et solidt bidrag til religionsfilosofisk forskning. Han magter at få en dialog mellem Habermas og Foucault i stand, der kaster et nyt lys over religionsvidenskabens status og indkredser en mulig opfattelse af religion på modernitetens betingelser. Hans konklusioner og synsvinkler kan diskuteres, hvilket dog - så lidt som den kritik, der er fremført ovenfor - på ingen måde kan stille spørgsmålstegn ved, at afhandlingen klart fortjener at belønnes med den teologiske doktorgrad. Hans afhandling er ikke kun et væsentligt bidrag til forskningen ved det daværende fakultets to hovedfag - teologi og religionsvidenskab - men bør hilses velkommen af hele universitetet, for et universitet har brug for en løbende selvrefleksion, der ikke mindst handler om forholdet mellem magt og kommunikation. 


\section{LITTERATUR}

Albinus, Lars

2010 Religion, magt og kommunikation. Filosofiske overvejelser over religionens betydning i moderniteten, set $i$ krydsfeltet mellem Foucault og Habermas, Aarhus Universitet Universitetsforlag, Århus.

Andersen, Svend

1989 Sprog og skabelse. Fænomenlogisk sprogopfattelse i lyset af analytisk filosofi, med henblik på det religiøse sprog, Gyldendal. København.

1998 "Kan Bibelen være Guds ord? Et sprogfilosofisk problem hos Sløk og Wolterstorff", Dansk Teologisk Tidsskrift 61 (3), 177-198.

Benjamin, Walter

2010 Das Kunstwerk im Zeitalter seiner technischen Reproduzierbarkeit, Suhrkamp, Frankfurt/M.

Dummett, Michael

2010 The Nature and Future of Philosophy, Columbia University Press, New York.

Habermas, Jürgen

1973 "Wahrheitstheorien", in: H. Fahrenbach, ed., Wirklichkeit und Reflexion. Festschrift für Walter Schulz, Günter Neske Verlag, Pfullingen.

1974 "Vorbereitende Bemerkungen zu einer Theorie der kommunikativen Kompetenz", Theorie der Gesellschaft oder Sozialtechnologie - Was leistet die Systemforschung?, Suhrkamp, Frankfurt/M.

1976 "Was heißt Universalpragmatik?”, in: K.O. Apel, ed., Sprachpragmatik und Philosophie, Suhrkamp, Frankfurt/M.

1981 Theorie des kommunikativen Handelns. Band 1. Handlungsrationalität und gesellschaftliche Rationalisierung, Suhrkamp, Frankfurt/M.

1982 Theorie des kommunikativen Handelns. Band 2. Zur Kritik der funktionalistischen Vernunft, Suhrkamp, Frankfurt/M

2004 Wahrheit und Rechtfertigung. Philosophische Aufsätze, Suhrkamp, Frankfurt/M.

Rorty, Richard, ed.

1992 The Lingustic Turn. Essays in Philosophical Method. With Two Retrospective Essays, The University of Chicago Press, Chicago, London.

Thomsen, Søren Ulrik

1986 En dans på gloser - eftertanker om den kunstneriske skabelsesproces, Vindrose, København.

Tugendhat, Ernst

1976 Vorlesungen zur Einführung in die sprachanalytische Philosophie, Suhrkamp, Frankfurt a/M.

Svend Andersen, professor, dr.theol.

Afdeling for Systematisk Teologi

Faculty of Arts, Aarhus Universitet 